\title{
Analysis of Genetic and Molecular Identity Among Field Isolates of the Rice Blast Fungus with an International Differential System, Rep-PCR, and DNA Sequencing
}

Junjie Xing, Longping Branch Institute, Postgraduate School, Central South University, Changsha, Hunan 410125, China; State Key Laboratory of Hybrid Rice, National Hybrid Rice Research and Development Center, Changsha, Hunan 410125, China; Yulin Jia, United States Department of Agriculture-Agricultural Research Service, Dale Bumpers National Rice Research Center, Stuttgart, AR 72160; James C. Correll, Department of Plant Pathology, University of Arkansas, Fayetteville 72701; Fleet N. Lee, Rice Research and Extension Center, University of Arkansas, Stuttgart; Richard Cartwright, Department of Plant Pathology, University of Arkansas, Fayetteville; and Mengliang Cao and Longping Yuan, State Key Laboratory of Hybrid Rice, National Hybrid Rice Research and Development Center, Changsha, Hunan 410125, China

\begin{abstract}
Xing, J., Jia, Y., Correll, J. C., Lee, F. N., Cartwright, R., Cao, M., and Yuan, L. 2013. Analysis of genetic and molecular identity among field isolates of the rice blast fungus with an international differential system, Rep-PCR, and DNA sequencing. Plant Dis. 97:491-495.

The $P$ - $t a$ gene deployed in southern U.S. rice germplasm is effective in preventing the infection by strains of Magnaporthe oryzae isolates that carry the avirulence $(A V R)$ gene AVR-Pital. In the present study, 169 isolates from rice (Oryza sativa) cultivars, with and without $P i$-ta, were analyzed for their genetic identity using an international differential system, repetitive element-based polymerase chain reaction (RepPCR), and sequence analysis of PCR products of AVR-Pital. These isolates belong to the races IA1, IB1, IB17, IC1, and IC17 of $M$. ory$z a e$. These isolates were further classified into 15 distinct groups by Rep-PCR. There was a predominant group within each race. Pathogenicity assays on 'Katy' (Pi-ta) and 'M202' (pi-ta) rice determined that IC1 was virulent to Katy and M202; IB17, IC17, and most of IA1 and IB1were avirulent to Katy and virulent to M202, suggesting that

the Pi-ta gene in Katy is responsible for preventing infection by these isolates. Consistently, AVR-Pital was not amplified from 28 virulent isolates. One AVR-Pital allele was amplified by AVR-Pital-specific primers in 78 avirulent isolates. Interestingly, different AVR-Pital alleles were found in each of the 12 avirulent isolates, as determined by DNA sequencing. Sequence analysis of 90 PCR products revealed 10 AVR-Pital haplotypes, 4 of which were new. In total, 12 amino acid changes were identified in the new variants when compared with the first described AVR-Pita sequence (AF207841). The finding of isolates with altered $A V R$-Pital from rice cultivars with and without $P i$-ta suggests that these virulent isolates were adapted to the field environments in the southern United States. Further research will be needed to verify this prediction.
\end{abstract}

Rice (Oryza sativa) feeds $50 \%$ of the human population and is under intensified cultivation in diverse geographic regions and climate conditions. Presently, rapid population growth, particularly in developing nations, has demanded increased production of rice. One of the most important bottlenecks for securing stable rice production is rice blast disease. Rice blast disease is caused by the ascomycete fungus Magnaporthe oryzae (formerly $M$. grisea (T.T. Hebert) M.E. Barr) (7). In commercial rice fields, M. oryzae is known to be transmitted via asexual spores by air or in close contact through dew or rain. Asexual spores germinate and infect rice tissue within a few hours of contact. The fungus absorbs nutrients from live rice cells for production of invasive mycelia and asexual spores. Disease symptoms can be observed as early as 3 days after infection in a greenhouse. Under high humidity and intensified rice production systems, blast can complete this infection cycle several times in a few months. As a result, rice

Corresponding author: Y. Jia, E-mail: yulin.jia@ars.usda.gov

This project is supported by the United States Department of Agriculture (USDA) Agricultural Research Service National Program 301 project "Responses of rice germplasm to biotic and abiotic stresses". USDA is an equal opportunity provider and employer.

* The $e$-Xtra $\log$ o stands for "electronic extra" and indicates that four supplementary tables are included in the online edition.

Accepted for publication 18 October 2012.

http://dx.doi.org/10.1094/PDIS-04-12-0344-RE

This article is in the public domain and not copyrightable. It may be freely reprinted with customary crediting of the source. The American Phytopathological Society, 2013. crop production is reduced and, sometimes, the entire crop can be lost.

Currently, rice blast disease is managed by the use of resistance $(R)$ genes integrated with sophisticated cultural management systems, including the use of fungicides. However, host resistance is the most economical and powerful method of controlling rice blast disease. Genetic resistance to blast follows a gene-for-gene model where a single dominant $R$ gene is effective in preventing $M$. oryzae strains that contain the corresponding avirulence $(A V R)$ gene (24). To date, over 80 dominant $R$ genes have been identified. Some $R$ genes were deployed and dozens of $R$ genes were molecularly characterized (2).

In the southern United States, the major blast $R$ gene $P i$-ta confers resistance to $M$. oryzae strains that contain AVR-Pita. Pi-ta was first deployed in the 1990s when 'Katy' rice was released (21). Subsequently, by using classic rice breeding methods, the Pi-ta gene has been transferred into a series of elite rice cultivars; namely, 'Drew', 'Madison', 'Kaybonnet', 'Cybonnet', 'Ahrent', 'Banks', 'Springs', and 'Catahoula' $(10,19,20,28)$. These cultivars have been grown throughout the southern United States, where blast is known to be problematic. Thus far, resistance mediated by $P i$ - $t a$ remains effective. However, virulent blast races, including IE1k and B2-B8, have been recovered from Pi-ta-containing rice cultivars in commercial rice fields in the southern United States $(8,28)$. Historical surveys of blast field isolates revealed that at least 10 common $M$. oryzae races initially identified in the $1960 \mathrm{~s}-$ namely, IA-45, IB-1, IB-45, IB-49, IB-54, IC-17, ID-1, IG-1, IE-1, and IH-1 (1) - are still present in contemporary rice fields (6). All of these races were shown to contain AVR-Pita alleles with minor modifications of their predicted products (8). Additionally, since it was discovered that AVR-Pita is a member of a small gene family, it was renamed as AVR-Pital to distinguish it from other family members (17). 
In order to monitor the genetic changes of M. oryzae, we have been studying genetic and molecular variations of $M$. oryzae strains. The fungi were isolated from rice cultivars with or without $P i$ - $t a$, random rice cultivars, and red rice at different growth stages of rice in rice fields, and crabgrass at the levee of rice fields. The objectives of this study were to determine (i) race identity using an international differential system, (ii) the genetic makeup of blast isolates using repetitive element-based polymerase chain reaction (Rep-PCR), (iii) disease reactions to rice cultivars with and without $P i$-ta, (iv) the existence of AVR-Pita within a strain, and (v) the structural and avirulent function of AVR-Pital.

\section{Materials and Methods}

Rice materials and growth. Rice plants were grown in a tray (20 9/16 by $103 / 16$ in. [ $5123 / 41$ by $258 / 41 \mathrm{~cm}$ ]) (Hummert) in a greenhouse at 25 to $30^{\circ} \mathrm{C}$ with $16 \mathrm{~h}$ of light for 3 weeks to reach the three- to four-leaf stage. Each rice cultivar-namely, 'Raminad Strain 3', 'Zenith', 'NP 125', 'Usen', 'Dular', 'Kanto 51', 'Shatiao-tsao', and 'Caloro' - was used for race identification as described in an international race differential system (18). Katy, the $P i$-ta-containing rice cultivar, was used to determine avirulence and 'M202', which does not carry Pi-ta, was used to determine virulence of all blast isolates, respectively.

Fungal isolates, spore suspensions, and pathogenicity assays. In the present study, 165 isolates of $M$. oryzae were collected from different rice cultivars in the rice fields of Arkansas in 1996 and 2009, and 4 isolates were collected from crabgrass on a levee of a rice field in 2008 (Supplementary Table S1). Among these isolates, 28 were collected from Pi-ta-containing cultivars; the remaining isolates were purified from random rice fields (cultivar unknown) in Arkansas. All isolates were purified, grown, and stored on desiccated filter papers at $-20^{\circ} \mathrm{C}$. Oatmeal agar and liquid complete medium were used for producing conidial inocula and mycelia, respectively. For all isolates, mycelia were produced in liquid complete medium broth for 7 days, shaken at $100 \mathrm{rpm}$ at 23 to $25^{\circ} \mathrm{C}$, and then separated using cheesecloth (Fiberweb) for DNA extraction.

For each inoculation, four to five filter discs containing mycelia and spores were removed from the freezer and then were grown on oatmeal agar plate for 7 to 10 days under blue and white fluorescent lighting (Atlanta light bulbs) at 23 to $25^{\circ} \mathrm{C}$. The spores on the oatmeal plate were scraped into $0.25 \%$ gelatin (ICN Biomedical, Inc.) with sterilized $\mathrm{H}_{2} \mathrm{O}$ under a flow hood. Spore suspensions were then filtrated using three to five layers of cheesecloth and concentration was determined using a hemacytometer (Hausser Scientific Company) as described by Sambrook, and Russell (23). A final concentration of spores of 1 to $8 \times 10^{6}$ spores $/ \mathrm{ml}$ was used for inoculating 200 to 300 rice seedlings in a tray (20 9/16 by 10 $3 / 16$ in. [51 23/41 by $258 / 41 \mathrm{~cm}]$ ) (Hummert).

Standard pathogenicity assays were conducted as previously described $(13,27)$. Specifically, rice seedlings at the three- to four-leaf stage were inoculated with spore suspensions inside a plastic bag. The bags were sealed to maintain 70 to $100 \%$ humidity for $24 \mathrm{~h}$ at 23 to $25^{\circ} \mathrm{C}$ in the laboratory. One day after inoculation, the inoculated bags were opened and rice seedlings were moved to a greenhouse for an additional 6 days to allow the full development of disease symptoms. The disease reaction was evaluated at 7 days after inoculation with a 0 -to-5-scale rating system, where 0 to 2 indicates resistance and 3 to 5 indicates susceptibility (27). The race identity was determined based on the disease reaction of eight

Table 1. List of DNA primers used in this study

\begin{tabular}{lll}
\hline Primer & \multicolumn{1}{c}{ Sequence $\mathbf{5}^{\prime}$ to $\mathbf{3}^{\prime}$} & \multicolumn{1}{c}{ Source } \\
\hline JX-1 & ACA AATTGATAAAACATT TA & This study \\
YL149 & TGACCGCGATTCCCTCCATT & 30 \\
YL169 & CGACCCGTTTCCGCC & 30 \\
Pot2-1 & CGGAAGCCCTAAAGCTGTTT & 9 \\
Pot2-2 & CCC TCATTCGTCACACGTTC & 9 \\
T7 & TAA TACGACTCACTATAGGGAA & Invitrogen \\
\hline
\end{tabular}

previously named cultivars in an international differential system, as previously described by Ling and $\mathrm{Ou}$ (18). In total, 15 isolates purified from $P i$-ta-containing Kaybonnet and Drew were retested to see whether the same disease reactions occurred using the above-mentioned procedure. This verified whether these isolates were virulent on Pi-ta-containing cultivars. All pathogenicity assays were repeated at least twice; in some cases, disease reaction was determined after a third test.

DNA extraction, Rep-PCR, $A V R$-Pita1 amplification, cloning, and sequencing. The fungal DNA was prepared using a Qiagen DNeasy Plant Mini Kit following the manufacturer's instructions (Qiagen Inc.). All PCR reactions were performed in a Peltier Thermal Cycler (PTC-200; MJ Research). Rep-PCR was performed as previously described (9). Briefly, primers Pot2-1 and Pot2-2 were used to detect genetic identity based on Rep-PCR (Table 1). Each Rep-PCR contained $25 \mu$ of Taq PCR Master Mix (Qiagen Inc.), 1 $\mu \mathrm{l}$ of each primer $(10 \mu \mathrm{M})$, about $30 \mathrm{ng}$ of fungal genomic DNA, and distilled water to $50 \mu \mathrm{l}$. Rep-PCR was performed as follows: 1 cycle of $95^{\circ} \mathrm{C}$ for $2.5 \mathrm{~min} ; 3$ cycles of $94^{\circ} \mathrm{C}$ for $1 \mathrm{~min}, 62^{\circ} \mathrm{C}$ for 1 min, and $65^{\circ} \mathrm{C}$ for $10 \mathrm{~min} ; 25$ cycles of $94^{\circ} \mathrm{C}$ for $30 \mathrm{~s}, 62^{\circ} \mathrm{C}$ for 1 $\mathrm{min}$, and $65^{\circ} \mathrm{C}$ for $10 \mathrm{~min}$; and 1 cycle of $65^{\circ} \mathrm{C}$ for $15 \mathrm{~min}$. Each Rep-PCR was repeated twice.

Primers YL169 and YL149 (Table 1) (30) were used to detect the presence of the AVR-Pital gene in all isolates. PCR amplifications were performed with Taq DNA polymerase (Takara Bio Inc.). PCR components were $0.25 \mu \mathrm{l}$ of Takara $\operatorname{Taq}(5 \mathrm{U} / \mu \mathrm{l}), 5 \mu \mathrm{l}$ of $10 \times \mathrm{PCR}$ buffer, $4 \mu \mathrm{l}$ of dNTP mixture $(2.5 \mathrm{mM}), 1 \mu \mathrm{l}$ of each primer $(10$ $\mu \mathrm{M}$ ), about $30 \mathrm{ng}$ of fungal genomic DNA, and distilled water to $50 \mu \mathrm{l}$. The PCR program for AVR-Pital was as follows: 1 cycle of $94^{\circ} \mathrm{C}$ for $3 \mathrm{~min} ; 29$ cycles of $94^{\circ} \mathrm{C}$ for $30 \mathrm{~s}, 55^{\circ} \mathrm{C}$ for $30 \mathrm{~s}$, and $72^{\circ} \mathrm{C}$ for $30 \mathrm{~s}$; and, finally, 1 cycle of $72^{\circ} \mathrm{C}$ for $5 \mathrm{~min}$. PCR products were purified from a gel with a QIA quick Gel Extraction Kit following the manufacturer's recommendations (Qiagen Inc.) and sequenced using primers YL169 and YL149 (Table 1). The Primer JX-1 (Table 1) was designed based on GenBank sequence (AF207841) to verify DNA sequences of the $3^{\prime}$ region of the AVRPital alleles. All other primers used in the present study are listed in Table 1. For DNA sequencing, $20 \mathrm{ng}$ of PCR product and $0.5 \mu \mathrm{l}$ of $1.6 \mu \mathrm{M}$ primer were added into each well in an ABI 3730XL DNA Analyzer using $0.5 \mu \mathrm{l}$ of BigDye v3.1 at the United States Department of Agriculture-Agricultural Research Service Mid South Area Genomics Laboratory at Stoneville, MS.

PCR reactions were repeated three times to produce products for sequencing. For those isolates when AVR-Pital DNA sequences could not be obtained from PCR products, their amplicons were cloned using a TOPO TA Cloning Vector (Invitrogen Corp.). After transformation, 10 individual colonies per isolate were selected (Supplementary Table S2) and sequenced with T7 $(0.5 \mu \mathrm{l}$ at $10 \mu \mathrm{M})$ (Table 1) using approximately $100 \mathrm{ng}$ of plasmid DNA.

DNA sequence data analysis. The AVR-Pital DNA sequences were analyzed by Vector NTI Suite V.11 (Invitrogen Corp.), and the haplotype network was constructed by MAGA 4.0 and TCS $1.21(5,24)$. DNA sequences were aligned using contig expression and edited based on repeated sequencing results to generate the AVR-Pital sequence assemblies. These sequence assemblies were then converted into FASTA format for MAGA 4, and sequence assemblies were aligned by ClustalW (25). The alignment was then exported as the FASTA format and converted to the Nexus format of the TCS on the website http://sing.ei.uvigo.es/ALTER/. To detect any correlation of virulent isolates with rice cultivars with or without $\mathrm{Pi}$-ta, independent tests were performed using the IBM SPSS statistics (version 19; IBM Corporation).

\section{Results}

Race identification and disease reaction on Katy and M202. Based on disease reactions on the eight international differential rice cultivars, five races were identified among the 169 isolates of M. oryzae. In all, 26 isolates belonged to IA1, 98 to IB1, 5 to IB17, 24 to IC1, and 12 to IC17. The four isolates from crabgrass failed to infect eight international rice cultivars and M202; hence, race 
identity was undetermined. M202 was susceptible to all isolates collected from rice and red rice, whereas Katy was susceptible to 27 isolates, including 24 IC1, 2 IA1, and 1 IB 1 , but resistant to the remaining 142 isolates.

Initially, we were interested in examining the occurrences of virulent isolates on Pi-ta-containing rice cultivars. Of these isolates, 28 were purified from $P i$-ta-containing cultivars Kaybonnet and Drew (Table 2); however, 20 were no longer infectious to Katy. A $\chi^{2}$ test of independence of isolate and host genotype in Table 2 demonstrated that there was a significant difference $(P$ value $=$ $0.007)$ in the occurrence of virulence between isolates from $P i$-ta and non-Pi-ta cultivars, and that the Pi-ta gene was related to the occurrence of the virulent isolates.

Genetic identity determined by Rep-PCR. In total, 15 different Rep-PCR patterns labeled as A to O were detected among all the isolates (Fig. 1; Supplementary Table S3; Table 3). There were 8 different patterns in IA1 group, 11 in IB1 group, 3 in IB17 group, 4 in IC1 group, and 3 in IC17 group. Among the isolates within each race group, there was one major pattern with a few other patterns (Table 3). Specifically, the D-type pattern was found in more isolates of the races IA1, IB1, and IB 17 while the $\mathrm{C}$ pattern was found in more isolates of the races IC1 and IC17.

Evolution of AVR-Pital. Using AVR-Pital-specific primers YL169 and YL149 (Table 1), a predicted 1-kb fragment was amplified from 90 avirulent isolates. In contrast, multiple fragments of 0.5 to $3 \mathrm{~kb}$ were amplified from nine virulent isolates of the IC1 race and one avirulent isolate of the IB1 race; no PCR products were amplified from the remaining 69 isolates. Sequence analysis of 0.5 - and $3-\mathrm{kb}$ fragments indicated that both were not specific to AVR-Pital, and they were not analyzed further. DNA sequence analysis of PCR amplicons in 90 isolates revealed 10 different haplotypes. Sequence alignment among these 10 haplotypes revealed 21 polymorphic sites (excluding gaps), 18 of which were in the exon region and three in the intron region. Of the 18 sites in the exon region, 17 had led to predicted amino acid substitutions, indicating that most sequence variations in the exon region had also resulted in amino acids alterations in the protein. In all, 6 of the 10 haplotypes were reported previously and 4 haplotypes were new findings (Table 4). Additionally, we found two or three AVR-Pital alleles in each of the 12 isolates using plasmids for sequencing (Supplementary Table S4). They were determined to be the haplotypes $1,36,40,41$, and 42 .

Table 2. Disease reactions on 'Katy' of Magnaporthe oryzae isolates purified from $\mathrm{Pi}$-ta- or non-Pi-ta-containing cultivars

\begin{tabular}{|c|c|c|c|}
\hline \multirow[b]{2}{*}{ Isolates } & \multicolumn{2}{|c|}{ Disease reaction of Katy } & \multirow[b]{2}{*}{ Total } \\
\hline & Susceptible & Resistant & \\
\hline$P i$-ta-containing ${ }^{\mathrm{a}}$ & 8 & 20 & 28 \\
\hline Non-Pi-ta-containing ${ }^{\mathrm{b}}$ & 6 & 69 & 75 \\
\hline Total & 14 & 89 & 103 \\
\hline
\end{tabular}

a $P i$-ta-containing 'Kaybonnet' and 'Drew'.

b Non-Pi-ta-containing 'Newbonnet', 'Bengal', 'CL151', 'CL142', 'CL11511',

'Francis', 'Jupiter', 'M206', 'Taggart', 'Wells', and 'RU0801145'.

\section{Discussion}

In the present study, we surveyed 165 field isolates of rice blast fungus in Arkansas, where most U.S. rice is grown. These isolates were determined to belong to the five races IA1, IB1, IB17, IC1, and IC17. Along with previous surveys, there are a total of 25 races among 291 isolates from the southern United States (8). Consistent with previous work, isolates of the races IB1, IB17, and IC17 were avirulent to Katy and virulent to M202, suggesting that the Pi-ta gene was responsible for preventing infections by these isolates. In addition, most IC1 isolates identified in this study were virulent to Katy. Rep-PCR were repeated for the IC1 and IC17 group using DNAs from newly grown fungus of the same isolate, and the results showed that the patterns were highly similar to one another (data not shown), suggesting that these Rep-PCR patterns can be used to rapidly estimate genetic identity of rice blast fungus.

Traditionally, the genetic identity of rice blast fungus was analyzed using restriction fragment length polymorphism based on the repetitive sequence MRG586 or Pot2 $(11,29)$. Rep-PCR was based on the repetitive element Pot2, an inverted repeat transposon (16), which has been widely applied in analyzing the genetic identity of fungal genomes $(3,6,12)$. In the present study, we found that RepPCR patterns of field blast isolates were reproducible even with different Taq polymerases or DNA preparations. Although there was not a perfect correlation between the race identified and the Rep-PCR pattern, one Rep-PCR pattern was found to predominate in each race group. The Rep-PCR pattern of IC1 was different from that of IElk, which also was known to infect Katy (30). The complexity of our Rep-PCR findings suggest that it may be a useful

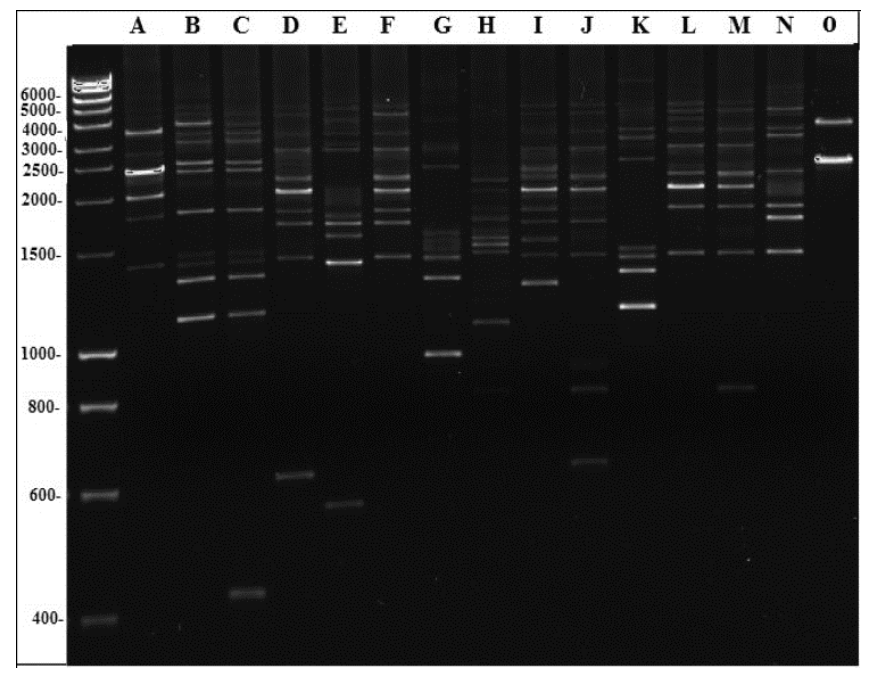

Fig. 1. Different repetitive element-based polymerase chain reaction pattern in all rice blast isolates. Lanes $\mathrm{A}$ through $\mathrm{O}$ represent different pattern types. Patterns $\mathrm{C}$ and $D$ predominate in all isolates. Molecular weights of each fragment are also estimated using Bio-Rad Gel Doc software and the data are summarized in Supplementary Table S3.

Table 3. Distribution of repetitive element-based polymerase chain reaction (Rep-PCR) pattern of isolates of Magnaporthe oryzae and M. grisea

\begin{tabular}{|c|c|c|c|c|c|c|c|c|c|c|c|c|c|c|c|c|c|}
\hline \multirow[b]{2}{*}{ Race } & \multirow[b]{2}{*}{$N^{\mathbf{b}}$} & \multicolumn{15}{|c|}{ Rep-PCR pattern ${ }^{a}$} & \multirow[b]{2}{*}{ Patterns } \\
\hline & & $\mathbf{A}$ & B & $\mathbf{C}$ & D & $\mathbf{E}$ & $\mathbf{F}$ & $\mathbf{G}$ & $\mathbf{H}$ & I & $\mathbf{J}$ & $\mathbf{K}$ & $\mathbf{L}$ & M & $\mathbf{N}$ & O & \\
\hline IA 1 & 26 & $\ldots$ & $\ldots$ & $\ldots$ & 9 & 1 & 7 & 3 & 1 & 3 & 1 & $\ldots$ & $\ldots$ & $\ldots$ & 1 & $\ldots$ & 8 \\
\hline IB1 & 98 & $\ldots$ & 1 & 3 & 49 & 5 & 16 & 4 & $\ldots$ & 4 & $\ldots$ & 2 & 9 & 4 & 1 & $\ldots$ & 11 \\
\hline IB17 & 5 & $\ldots$ & $\ldots$ & $\ldots$ & 3 & $\ldots$ & $\ldots$ & 1 & $\ldots$ & 1 & $\ldots$ & $\ldots$ & $\ldots$ & $\ldots$ & $\ldots$ & $\ldots$ & 3 \\
\hline IC1 & 24 & $\ldots$ & 3 & 16 & $\ldots$ & $\ldots$ & $\ldots$ & $\ldots$ & $\ldots$ & $\ldots$ & 1 & 3 & $\ldots$ & $\ldots$ & $\ldots$ & $\ldots$ & 4 \\
\hline IC17 & 12 & $\ldots$ & $\ldots$ & 8 & $\ldots$ & $\ldots$ & $\ldots$ & $\ldots$ & $\ldots$ & $\ldots$ & $\ldots$ & 3 & 1 & $\ldots$ & $\ldots$ & $\ldots$ & 3 \\
\hline Grass $^{\mathrm{d}}$ & 3 & 1 & $\ldots$ & $\ldots$ & $\ldots$ & $\ldots$ & $\ldots$ & $\ldots$ & $\ldots$ & $\ldots$ & $\ldots$ & $\ldots$ & $\ldots$ & $\ldots$ & $\ldots$ & 2 & 2 \\
\hline Total & 168 & 1 & 4 & 27 & 61 & 6 & 23 & 8 & 1 & 8 & 2 & 8 & 10 & 4 & 2 & 2 & $\ldots$ \\
\hline
\end{tabular}

\footnotetext{
${ }^{\text {a }}$ Rep-PCR pattern shown in Figure 1.

${ }^{b}$ Number of isolate in each race.

${ }^{c}$ Total number of different Rep-PCR patterns.

d Isolates of $M$. grisea purified from crabgrass.
} 
way to look at genetic diversity, especially if AVR-Pital and other virulent genes that affect race are under positive selection or horizontally transferred.

The Pi-ta gene in rice is known to recognize the AVR-Pital allele in races of $M$. oryzae (14). The effectiveness of the Pi-ta gene in diverse genetic backgrounds was previously investigated (15). In total, $13 \mathrm{Pi}$-ta- and $\mathrm{Pi}$-ta2-containing rice cultivars were resistant and $7 \mathrm{pi}$-ta-containing rice cultivars were susceptible to the races IC17 and IB49, respectively. With $P i$-ta-specific markers, we showed that all Pi-ta2 cultivars also contained Pi-ta (15). Whether or not $P i$-ta and $P i$-ta2 are involved in recognizing the same pathogen signal molecule remains to be determined. The isolates that we characterized as avirulent and virulent toward Katy in this study would be useful for the investigation of pathogen recognition specificity using additional rice germplasm that carry $P i$ - $t a$. The monogenic lines with 24 major blast $R$ genes developed by the International Rice Research Institute-Japan Collaborative Research Project (26) will be useful to verify $P i-t a / A V R-P i t a l$ interaction, and identify additional $R$ genes to blast isolates.

The specific marker YL149/YL169 was previously demonstrated to predict the existence of the AVR-Pital gene using PCR. The absence of PCR amplicons as indicative of the absence of AVRPital was previously established using Southern blot analysis $(8$, 30). In this study, the AVR-Pital allele was consistently amplified by YL149/YL169 from 90 avirulent isolates. Sequence analysis revealed 10 different $A V R$-Pital haplotypes, of which 4 were new haplotypes designated as haplotypes 39 to 42 (Fig. 2). The other isolates that have AVR-Pital belong to haplotypes 1, 11, 14, 16, 18, and 36 . The haplotype sequences predict eight protein variants that are similar to the first reported AVR-Pital sequence. Among these eight variant proteins, amino acid variations were predicted to occur at 15 positions, including the amino acid residue 173 that exists in the conserved region of AVR-Pital (22). These findings support the idea that evolution of AVR-Pita alleles may involve protein modifications while maintaining their avirulence protein function (22). Interestingly, we found 12 isolates that contain two or three different AVR-Pita haplotypes. The chromosomal location and organization of these AVR-Pita haplotypes are undetermined; nevertheless, this finding is similar to the report that approximately two copies of AVR-Pita were found in some M. oryzae isolates collected from Asia (4). Both studies demonstrate that the AVRPita family has evolved through a highly complicated mechanism

Table 4. Amino acid variation among the avirulence (AVR)-Pita1 proteins

\begin{tabular}{|c|c|c|c|c|c|c|c|c|c|c|c|c|}
\hline \multirow[b]{2}{*}{ Protein } & \multicolumn{12}{|c|}{ Amino acids $^{\mathbf{a}}$} \\
\hline & $*$ & 59 & 81 & 87 & 103 & 118 & 135 & 173 & 191 & 194 & 206 & 222 \\
\hline $\mathrm{H} 38^{\mathrm{b}}$ & $\ldots$ & $\mathrm{S}$ & $\mathrm{N}$ & $\mathrm{R}$ & K & E & G & V & Y & D & $\mathrm{K}$ & $\mathrm{Y}$ \\
\hline $\mathrm{H} 39^{\mathrm{c}}$ & $\mathrm{L}$ & $\mathrm{S}$ & $\mathrm{S}$ & K & $\mathrm{N}$ & $\mathrm{Q}$ & E & I & $\mathrm{C}$ & D & $\mathrm{K}$ & Y \\
\hline $\mathrm{H} 40^{\mathrm{c}}$ & $\mathrm{L}$ & $\mathrm{C}$ & $\mathrm{N}$ & $\mathrm{R}$ & $\mathrm{K}$ & E & G & I & C & $\mathrm{H}$ & $\mathrm{K}$ & $\mathrm{N}$ \\
\hline $\mathrm{H} 41^{\mathrm{c}}$ & $\mathrm{L}$ & $\mathrm{C}$ & $\mathrm{N}$ & $\mathrm{R}$ & K & E & G & V & C & $\mathrm{D}$ & $\mathrm{R}$ & $\mathrm{Y}$ \\
\hline $\mathrm{H} 42^{\mathrm{c}}$ & $\mathrm{L}$ & $\mathrm{S}$ & $\mathrm{S}$ & K & $\mathrm{N}$ & E & E & I & $\mathrm{C}$ & $\mathrm{H}$ & $\mathrm{K}$ & $\mathrm{N}$ \\
\hline
\end{tabular}

${ }^{\text {a }}$ Numbers above each column indicate amino acid position in the AVR-Pita1 protein (AF207841); * indicates the absence of amino acid. Single-letter code was used for each amino acid.

${ }^{b}$ Indicates the original AVR-Pita1 protein (AF207841); the same number was used for each AVR-Pita1 haplotype in Figure 2.

c GenBank accession numbers: H39, JX467664; H40, JX467665; H41, JX467666; and H42, JX467667.

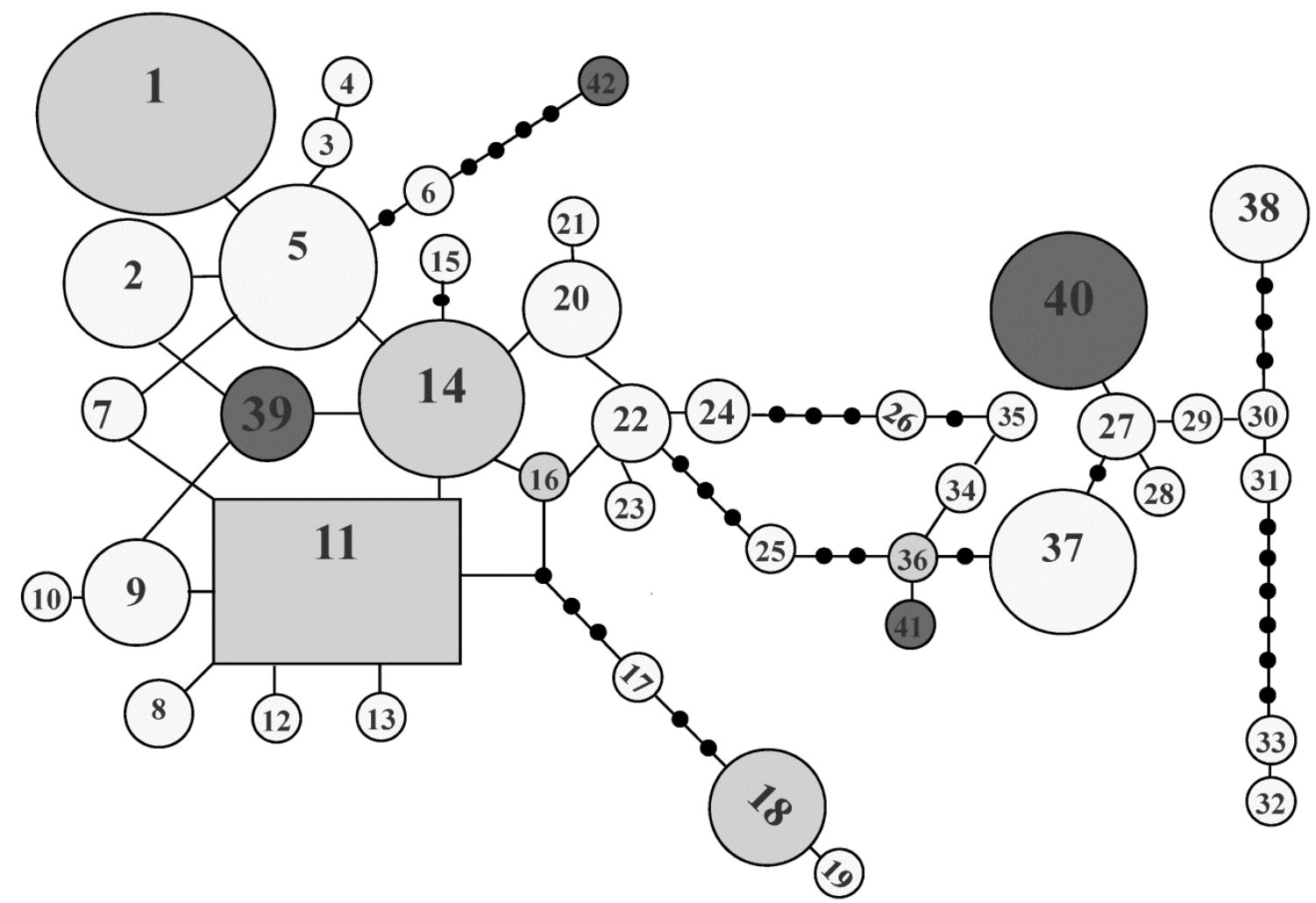

Fig. 2. Haplotype network for different avirulence (AVR)-Pita1 alleles. $\mathrm{H} 1$ through $\mathrm{H} 38$ were reported by Dai et al. (8). Haplotypes in medium and dark gray were found in the present study. Those in dark gray ( $\mathrm{H39}, 40,41$, and 42$)$ were novel haplotypes and those in medium gray were previously found (8). The rectangle stands for the original haplotype, each circle stands for one unique haplotype, and there is 1-bp change between two connected circles. The size of circle represents the relative frequency of the haplotype in the population. Each black node on the line shows a missing haplotype. 
$(4,22)$. Additionally, AVR-Pital can be amplified from all four isolates collected from crabgrass, and the AVR-Pital allele from three of four isolates belonged to the haplotype 18 . This was consistent with an earlier reported by Dai et al (8). All these crabgrass isolates were avirulent to the tested rice cultivars, suggesting that these isolates were not pathogenic toward rice. Because crabgrass in the present study was located near the levee of rice fields, an investigation of the role of AVR-Pital in crabgrass would lead to a better understanding of the evolution of AVR-Pita in Magnaporthe spp. (17).

It is not difficult to predict high variability for any gene that is located at the telemetric region. This is the case for the AVR-Pital gene. A sophisticated mechanism involving deletion, point mutation, and transposon insertion has been documented in virulent isolates. In avirulent isolates, more than 40 AVR-Pital variants have been reported $(4,8,30)$. The occurrence of virulent isolates in rice cultivars with or without $\mathrm{Pi}$-ta suggests that blast fungus can survive in the southern United States. Moreover, the occurrence of virulent isolates was associated more with rice cultivars with Pi-ta. These findings suggest that virulent field isolates of $M$. oryzae in Arkansas are evolving by the selective pressure imposed by the $P i$ $t a$ gene in host plants.

\section{Acknowledgments}

We thank the Arkansas Rice Research and Promotion Board and China National Hybrid Rice Research and Development Center for supporting J. Xing's living and traveling expenses, E. McWhirter for proofreading the manuscript, and all other supporting staff of the Dale Bumpers National Rice Research Center for excellent technical support.

\section{Literature Cited}

1. Atkins, A., Robert, A., Adair, C., Goto, K., Kozaka, T., Yanagida, R., Yamada, M., and Matsumoto, S. 1967. An international set of rice varieties for differentiating race of Pyricularia oryzae. Phytopathology 57:297-301.

2. Ballini, E., Morel, J. B., Droc, G., Price, A., Courtois, B., Notteghem, J. L., and Tharreau, D. 2008. A genome-wide meta-analysis of rice blast resistance genes and quantitative trait loci provides new insights into partial and complete resistance. Mol. Plant-Microbe Interact. 21:859-868.

3. Chen, Q. H., Wang, Y. C., and Zheng, X. B. 2006. Genetic diversity of Magnaporthe grisea in China as revealed by DNA fingerprint haplotypes and pathotypes. J. Phytopathol. 154:361-369.

4. Chuma, I., Isobe, C., Hotta, Y., Ibaragi, K., Futamata, N., Kusaba, M., Yoshida, K., Terauchi, R., Fujita, Y., Nakayashiki, H., Valent, B., and Tosa, Y. 2011. Multiple translocation of the AVR-Pita effector gene among chromosomes of the rice blast fungus Magnaporthe oryzae and relate $\mathrm{d}$ species. PLoS Pathog. 7:1-20.

5. Clement, M., Posada, D., and Crandall, K. A. 2000. TCS: A computer program to estimate gene genealogies. Mol. Ecol. 9:1657-1659.

6. Correll, J. C., Harp, T. L., Guerber, J. C., Zeigler, R. S., Liu, B., Cartwright, R. D., and Lee, F. N. 2000. Characterization of Pyricularia grisea in the United States using independent genetic and molecular markers. Phytopathology 90:1396-1404.

7. Couch, B. C., and Kohn, L. M. 2002. A multilocus gene genealogy concordant with host preference indicates segregation of a new species, Magnaporthe oryzae, from M. grisea. Mycologia 94:683-693.

8. Dai, Y., Jia, Y., Correll, J., Wang, X., and Wang, Y. 2010. Diversification and evolution of the avirulence gene AVR-Pital in field isolates of Magnaporthe oryzae. Fungal Genet. Biol. 47:973-980.

9. George, M. L. C., Nelson, R. J., Zeigler, R. S., and Leung, H. 1998. Rapid population analysis of Magnaporthe grisea by using Rep-PCR and endogenous repetitive DNA sequences. Phytopathology 88:223-229.
10. Gibbons, J. W., Moldenhauer, K. A. K., Gravois, K., Lee, F. N., Bernhardt J. L., Meullenet, J. F., Bryant, R., Anders, M., Norman, R. J., Cartwright, R., Taylor, K., Bulloch, J., and Blocker, M. M. 2006. Registration of 'Cybonnet' rice. Crop Sci. 46:2317-2318.

11. Hamer, J. E., Farrall, L., Orbach, M. J., Valent, B., and Chumley, F. G. 1989. Host species-specific conservation of a family of repeated DNA sequences in the genome of a fungal plant pathogen. Proc. Natl. Acad. Sci. USA 86:9981-9985.

12. Javan-Nikkhah, M., McDonald, B. A., Banke, S., and Hedjaroude, G. A. 2004. Genetic structure of Iranian Pyricularia grisea populations based on Rep-PCR fingerprinting. Eur. J. Plant Pathol. 110:909-919.

13. Jia, Y., and Martin, R. 2008. Identification of a new locus, $\operatorname{Ptr}(t)$, required for rice blast resistance gene Pi-ta-mediated resistance. Mol. Plant-Microbe Interact. 21:396-403.

14. Jia, Y., McAdams, S. A., Bryan, G. T., Hershey, H. P., and Valent, B. 2000. Direct interaction of resistance gene and avirulence gene products confers rice blast resistance. EMBO J. 19:4004-4014.

15. Jia, Y., Wang, Z., Fjellstrom, R. G., Moldenhauer, K. A. K., Azam, M. A., Correll, J., Lee F. N., Xia Y., and Rutger J. N. 2004. Rice Pi-ta gene confers resistance to the major pathotypes of the rice blast fungus in the United States. Phytopathology 94:296-301.

16. Kachroo, P., Leong, S. A., and Chattoo, B. B. 1994. Pot2, an inverted repeat transposon from the rice blast fungus Magnaporthe grisea. Mol. Gen. Genet. 245:339-348.

17. Khang, C. H., Park, S. Y., Lee, Y. H., Valent, B., and Kang, S. 2008. Genome organization and evolution of the AVR-Pita avirulence gene family in the Magnaporthe grisea species complex. Mol. Plant-Microbe Interact. 21:658-670.

18. Ling, K. C., and Ou, S. H. 1969. Standardization of the international race numbers of Pyricularia oryzae. Phytopathology 59:339-342.

19. Moldenhauer, K. A. K., Gibbons, J. W., Lee, F. N., Bernhardt, J. L., Wilson, C. E., Cartwright, R. D., Anders, M. M., Norman, R. J., Blocker, M. M., Boyett, V. A., Tolbert, A. C., Taylor, K., and Bulloch, J. M. 2007. Registration of 'Banks' rice. Crop Sci. 47:445-446.

20. Moldenhauer, K. A. K., Gravois, K. A., Lee, F. N., Norman, R. J., Bernhardt, J. L., Wells, B. R., Dilday, R. H., Blocker, M. M., Rohman, P. C., and McMinn, T. A. 1998. Registration of 'Drew' rice. Crop Sci. 38:896-897.

21. Moldenhauer, K. A. K., Lee, F. N., Norman, R. J., Helms, R. S., Wells, B. R., Dilday, R. H., Rohman, P. C., and Marchetti, M. A. 1990. Registration of 'Katy' rice. Crop Sci. 30:747-748.

22. Orbach, M. J., Farrall, L., Sweigard, J. A., Chumley, F. G., and Valent, B. 2000. A telomeric avirulence gene determines efficacy for the rice blast resistance gene Pi-ta. Plant Cell 12:2019-2032.

23. Sambrook, J., and Russell, D. W. 2001. Pages 3:8.46-48.53 in: Molecular Cloning: A Laboratory Manual. Cold Spring Harbor Laboratory, Cold Spring Harbor, NY.

24. Silué, D., Nottenghem, J. L., and Tharreau, D. 1992. Evidence for a genefor-gene relationship in the Oryza sativa-Magnaporthe grisea pathosystem. Phytopathology 82:577-580.

25. Tamura, K., Dudley, J., Nei, M., and Kumar, S. 2007. MEGA4: molecular evolutionary genetics analysis (MEGA) software version 4.0. Mol. Biol. Evol. 24:1596-1599.

26. Tsunematsu, H., Yanoria, M. J. T., Ebron, L. A., Hayashi, N., Ando, I., Kato, H., Imbe, T., and Khush, G. S. 2000. Development of monogenic lines of rice for rice blast resistance. Breed. Sci. 50:229-234.

27. Valent, B., Farrall, L., and Chumley, F. G. 1991. Magnaporthe grisea genes for pathogenicity and virulence identified through a series of backcrosses. Genetics 127:87-101.

28. Wells, B. R., Dilday, R. H., Rohman, P. C., and Blocker, M. M. 1995. Registration of 'Kaybonnet' rice. Crop Sci. 35:587-588.

29. Xia, J. Q., Correll, J. C., Lee, F. N., Ross, W. J., and Rhoads, D. D. 2000 Regional population diversity of Pyricularia grisea in Arkansas and the influence of host selection. Plant Dis. 84:877-884.

30. Zhou, E., Jia, Y., Singh, P., Correll, J. C., and Lee, F. N. 2007. Instability of the Magnaporthe oryzae avirulence gene AVR-Pita alters virulence. Fungal Genet. Biol. 44:1024-1034. 